\title{
Review: The Fantastic Worlds of Yuri Vynnychuk (2016)
}

Yuri Vynnychuk, translated by Michael M. Naydan

London 2016: Glagoslav Publications

Paperback, 276 pages

Yuri Vynnychuk, long celebrated as an underground author in Ukraine, has already made it onto the school curriculum in his native country, but he remains practically unknown in western Europe. Michael Naydan's new volume of Vynnychuk's work translated into English seeks to change this unfortunate state of affairs. The first part of the book is divided into four sections, each of which represents a literary style or mode used by Vynnychuk in his short stories: lyrical and philosophical, psychological, fantasy, and black humour and satire. The second part of the book is dedicated to extracts from Vynnychuk's longer prose works, including his novel that revisits Lviv during the Second World War, 'Tango of Death.' As Naydan sets out in his introduction, his aim is to showcase the author's virtuosic versatility, yet a broader motive emerges as well: creating a portrait of western Ukraine in all its glory. Naydan's book places Vynnychuk at the centre of a vibrant, folkloric and occasionally absurd world that changes as often as the voice that records it.

Naydan, professor of Ukrainian Studies at Pennsylvania State University, is a seasoned translator with more than 50 literary translations and a handful of awards under his belt. Here he offers a set of subtle, nuanced translations that capture the spirit of the original works. Some of the dialogue has clearly been Americanised, but enough Ukrainian words and details have been preserved to retain the local colour of the stories. Naydan's eloquent introduction, which outlines Vynnychuk's biography and assesses his literary influences and narrative devices, is a persuasive contribution to analysis of contemporary Ukrainian literature and could well be expanded to form a volume of its own.

The short stories themselves are astonishingly varied. 'An Embroidered World,' which begins the collection, is a triumph of magical realism. The premise of a grandmother who can visit death on living things (and reverse it) by the simple act of sewing echoes ancient Greek mythology and takes on a significant allegorical dimension. The piece is beautifully crafted and ends on an unexpectedly abrupt note, provoking a whole host of questions about life, death, fate and chronology. At the other end of the 
spectrum are 'The Pulsing Beacon,' a bizarre, sci-fi riff on extraterrestrials disguised as rabbits in the Ukrainian countryside, and 'Max and Me,' a riotous, dark tale not dissimilar to Sweeney Todd. Vynnychuk's stories are frequently crude and scatological - especially his satire on the Soviet Union set in Arcanumia, a land made entirely from human excrement - which contrasts strikingly with moments of sublime beauty and delicacy. The prose is alternately charming and unnerving, triggering sudden bursts of laughter even in the midst of narrative cruelty or indifference.

Engagement with contemporary Ukrainian identity is at the heart of nearly all of Vynnychuk's writing, but is especially prominent in 'Welcome to Ratburg,' which Naydan files under 'Black Humour and Satire.' In this story, Vynnychuk offers a critical reflection on post-Chernobyl Ukraine and betrays a deep-rooted anxiety about the fragile boundary between humans and animals that recurs throughout the collection. His narrator muses at length about a 'nation of lyric poets and not warriors $[\ldots]$ doomed to perish $[\ldots]$ just a throng, unified by language, embroidery, and songs about eternal life,' drawing on concerns that have troubled Ukrainian patriots for several centuries and are still highly relevant in today's political climate. The Soviet legacy is not forgotten either, with the fervent propaganda of the dictator rat state used as a transparent metaphor for the mythology that perpetuated the U.S.S.R..

The greatest strength of Naydan's collection is the critical lenses it provides the reader for analysis of Vynnychuk's work. By grouping the author's works together based on their literary mode, Naydan ensures that the myriad references, influences and word games embedded in the texts are clearly identifiable. His categories guide the reader and stimulate discussion without being overbearing and shutting down creative responses to the texts. Elements of the grotesque, the classical, the fairy tale and more all emerge and dissolve in Vynnychuk's prose, and this realisation is partly due to the emphasis that Naydan places on the writer's versatility and range. The extracts from Vynnychuk's novels that make up the second part of the book are arguably the best pieces of the collection, and Naydan has certainly chosen some thought-provoking and darkly funny episodes to include.

Yet this is also the source of the book's principal weakness. Reducing the novels to a single chapter or extract diminishes their intricacies and narrative arc, to the extent that the collection feels incomplete. After a selection of self-contained short stories, the fragments of the longer works are disappointing, in spite of the undeniable brilliance of 
the writing and translation. Master works such as 'Tango of Death' and 'Malva Landa' need to be read in their entirety to be fully appreciated, and for the historical context and significance to be understood. In addition, more attention paid to proofreading could have eliminated some typing errors that mar what is otherwise an impressive, polished collection.

All things considered, Naydan's new collection of works by Vynnychuk is an invaluable resource, especially as an introduction for those unfamiliar with his writing or with contemporary Ukrainian fiction more generally. For those interested in western Ukraine, that land of cultural crossover and linguistic plurality, it is similarly worthwhile, as Vynnychuk's colourful sketches bring the city of Lviv and its surrounding countryside to life. Above all, this publication is welcome at a point in time when educating people about the depth and quality of Ukrainian culture and literature is more necessary than ever.

\section{HELENA KERNAN}

University of Cambridge

This work is licensed under a Creative Commons Attribution-No Derivatives 4.0 International License. To view a copy of this license, visit https:// creativecommons.org/licenses/by-nd/4.0/. 